\title{
Delayed Multiplication of Newly Capsulated Transformants of Haemophilus influenzae Detected by Immunofluorescence
}

\author{
By B. W. CATLIN AND V. R. TARTAGNI \\ Department of Microbiology, Marquette School of Medicine, \\ Milwaukee, Wisconsin 53233, U.S.A.
}

(Accepted for publication 27 February 1969)

\section{SUMMAR Y}

Capsular transformation of Haemophilus influenzae strain RD was examined at the cellular level by a semi-quantitative method. Type $b$ capsular antigen synthesized by transformants was detected by its reaction with type $b$ antibody conjugated to fluorescein isothiocyanate. Deoxyribonucleate (DNA) preparations from type $b$ capsular transformants of strain RD elicited somewhat higher frequencies of transformation than preparations from type $b$ clinical isolates. Str- $r$ markers on these DNAs conferred resistance to a concentration of $500 \mu \mathrm{g}$. dihydrostreptomycin sulphate $/ \mathrm{ml}$. For a given DNA, the frequency of transformation to streptomycin resistance was at least Ioo times higher than that to capsular synthesis. The time course of expression of the two phenotypes by DNA-treated bacteria was examined in broth in which the generation time of the total population was about $50 \mathrm{~min}$. Resistant transformants began to appear $25 \mathrm{~min}$. after initiation of treatment and capsulated bacteria were observed after $40 \mathrm{~min}$. Both properties continued to be expressed until about $\mathrm{I} 20 \mathrm{~min}$. Thereafter, the behaviour of recipients of the two kinds of genetic markers differed. The rate of increase of the str-r transformants became equal to that of the total population, and in a subculture diluted $\mathrm{I} / 20$ they increased 20 -fold during subsequent incubation for $150 \mathrm{~min}$. The number of capsulated transformants, on the other hand, increased less than two-fold over the period $120-330 \mathrm{~min}$.

\section{INTRODUCTION}

The capsules of Haemophilus influenzae are composed of various immunologically distinct compounds (Leidy, Hahn, Zamenhof \& Alexander, 1960), those of type b being polyribophosphate (Rosenberg \& Zamenhof, I96I). The colonies produced by capsulated $H$. influenzae are smooth and highly iridescent. Occasionally, spontaneous genetic changes occur which result in inability to produce capsules, and these mutants can be detected by the lack of iridescence of their colonies (Pittman, I93I). From a type $\mathrm{d} H$. influenzae clinical isolate, Alexander \& Leidy (I95I) selected such a noncapsulated, non-iridescent strain, RD, and showed serologically that it failed to synthesize capsular antigen. By transformation, however, a fraction of the population of recipient strain RD may regain the ability to produce capsules and, accordingly, the typical colonial iridescence. The serological specificity of the transformant capsules depends on the specific genetic information supplied, being type $d$ or type $b$ in accordance with the capsular type of the DNA-donor (Alexander \& Leidy, 195I). Furthermore, 
the production of new capsular types ( $\mathrm{ab}$ or ad) by transformants of strain RD was demonstrated (Leidy, Hahn \& Alexander, 1953).

Investigations of capsular transformation were hampered, however, by inability to examine the kinetics of transformation at the cellular level. The low frequencies of transformation prohibited direct observation and enumeration of bacteria which developed capsules following phenotypic expression of the information specified by the entering DNA molecules. Although various methods have been employed in previous studies of capsular transformation, they have all dealt exclusively with those altered bacteria which are capable of multiplying to produce recognizable transformant clones (e.g. Alexander \& Leidy, 195I; Ravin, I954; Bernheimer, Wermundsen \& Austrian, 1967).

Immunofluorescence techniques now available provide a means of tracing specific bacterial antigens (e.g. Sell, Cheatham, Young \& Welch, I963; Biegeleisen, Marcus, Dawson \& Cherry, I965; Cole, 1965).

We have used immunofluorescence to examine the type b capsular antigen which is synthesized soon after the non-capsulated Haemophilus influenzae recipients are treated with transforming DNA. To aid in analysing and interpreting the kinetics of the reaction, streptomycin resistance was followed in parallel tests. This familiar reference marker provided valuable quantitative data on competence of the recipient bacteria and genetic activities of the DNA preparations, as well as on times of phenotypic expression and multiplication of the str-r transformants.

\section{METHODS}

Growth factors. The X and V requirements of Haemophilus influenzae were satisfied by solutions of haemin (recrystallized, Nutritional Biochemicals Corp., Cleveland, Ohio) and nicotinamide adenine dinucleotide (NAD, P. L. Biochemicals Inc., Milwaukee, Wis.). Haemin was dissolved (200 mg. in Io ml. of $0.1 \mathrm{M}-\mathrm{NaOH}$, with subsequent addition of water to give a final volume of $100 \mathrm{ml}$.) and was autoclaved at $\mathrm{I} 2 \mathrm{I}^{\circ}$ for $\mathrm{I} 5 \mathrm{~min}$. Biological activity of this haemin solution tended to deteriorate at $4^{\circ}$, as noted (Catlin, 1958), but was preserved for more than 2 years at $-18^{\circ}$. The stock solution of NAD $(5 \mathrm{mg} . / \mathrm{ml}$. water) was sterilized by filtration (Millipore, $0.45 \mu$, type HA membrane). These solutions were stored in small volumes in the frozen state until used.

Media. Three kinds of medium were used. HIY + HD was composed of heart infusion broth (Difco) with yeast extract (Difco, used at $0.3 \%, \mathrm{w} / \mathrm{v}$ ); before use, it was supplemented aseptically with solutions of glucose (final concentration, $0 \cdot \mathrm{I} \% \mathrm{w} / \mathrm{v}$ ) together with haemin and NAD (final concentration of each, Io $\mu \mathrm{g} . / \mathrm{ml}$.). BHI + HD broth was brain heart infusion (Difco) supplemented with haemin and NAD (Io $\mu \mathrm{g}$.) $\mathrm{ml}$.). The stock solution for Levinthal broth was prepared as described by Alexander (1965) except that human blood was used; this was combined with an equal volume of BHI supplemented with $5 \mu \mathrm{g}$. NAD $/ \mathrm{ml}$. (no haemin was added). HIY + HD agar had the same composition as the liquid but was solidified with $\mathrm{I} \cdot 0 \% \mathrm{w} / \mathrm{v})$ Ionagar no. 2 (Oxoid) for hard agar plates, or with $0.5 \%$ Ionagar no. 2 for soft agar overlays.

Antibody. Haemophilus influenzae type $\mathrm{b}$ antiserum for reference purposes was obtained from the Biological Reagents Section of the National Communicable 
Disease Center (Atlanta, Georgia). Also, type b antiserum was obtained commercially from Hyland Laboratories (Los Angeles, California), and a portion of this was conjugated with fluorescein isothiocyanate by Hyland. This immunofluorescent reagent was used to check the capsules of cultures used for DNA extraction and for immunization.

Antiserum for preparation of additional fluorescein-tagged antibody (FTA) was obtained by immunization of albino rabbits. The suspension of strain SB Sm 1000 used as antigen was freshly prepared each second week from $6 \mathrm{hr}$ BHI + HD cultures, care being taken to obtain well-capsulated bacteria. They were sedimented by centrifugation at $3^{\circ}$, and were washed and resuspended in chilled phosphate-buffered saline $(\mathrm{pH} 7 \cdot 2)$ containing $0.5 \%(\mathrm{v} / \mathrm{v})$ formaldehyde solution. Precautions emphasized by Alexander (1965) and Alexander, Leidy \& MacPherson (I946) were observed to minimize degeneration of the capsular antigen.

After precipitation with ammonium sulphate, the antibody was conjugated to fluorescein isothiocyanate (Baltimore Biological Laboratories) as described by Cherry, Goldman, Carski \& Moody (I960). Sephadex G25 (medium grade, Pharmacia Fine Chemicals, Inc.) was used for removal of unreacted fluorescein, as recommended by Gordon, Edwards \& Tompkins (1962). Polyethylene glycol 20,000 (Fisher Sci. Co.) was used to concentrate the conjugate (Kohn, 1959). The final product was filtered through a Millipore membrane $(0.45 \mu)$.

Strains. The seven strains of Haemophilus influenzae used in this work are characterized in Table I. All showed typical nutritional requirements; that is, growth occurred on HIY + HD agar, but not on HIY agar with haemin only or NAD only. Strains RD and SB sm IOOO (Santo) were provided by Miss Grace Leidy, and have been described (Alexander \& Leidy, 1953). Strains designated str-r, and referred to as streptomycin-resistant, were isolated by growth in HIY + HD broth or agar which contained dihydrostreptomycin sulphate (DHS, Pfizer) $500 \mu \mathrm{g} . / \mathrm{ml}$. Methods similar to those described for Neisseria (Catlin \& Cunningham, I964), were used to obtain the single-step spontaneous str mutants, and to preserve the strains by freezing.

All capsulated bacteria gave a positive Quellung reaction in type $b$ antiserum (from NCDC), and a brilliant capsular stain with the immunofluorescent reagent. Young colonies of capsulated strains showed a marked iridescence when viewed with strong light obliquely transmitted, as described by Pittman (I93I). Typical iridescent colonies observed with the aid of $\times 9$ magnification were subcultured after I4-18 hr incubation. Each of the strains appeared to be relatively homogeneous as determined by FTA-staining of the capsules, except RD(b)BR str-r. This strain, even after repeated single-colony isolation, usually showed a few (less than $0 \cdot 1 \%$ ) bacteria with narrow capsules in addition to the typical heavily capsulated rods (Pl. I, fig. 3).

Transforming DNA. Preparations were made from cultures of five strains (Table I). Cultures in HIY + HD broth containing $200 \mu \mathrm{g}$. DHS $/ \mathrm{ml}$. were incubated at $37^{\circ}$ with shaking for $5^{-6} \mathrm{hr}$. They were harvested by centrifugation at $3^{\circ}$ before attaining maximal turbidity (to reduce the likelihood that mutants involving altered capsulation might be selected). The sedimentated bacteria were washed twice in SSC (a solution containing $0.15 \mathrm{M}-\mathrm{NaCl}+0.015 \mathrm{M}$-sodium citrate), and were resuspended in SSC and frozen.

When thawed, the bacteria were lysed with sodium dodecyl sulphate $(0 \cdot 5-\mathrm{I} \cdot 0 \%$, w/v) in the presence of Pronase ( $1 \cdot 0 \mathrm{mg} . / \mathrm{ml}$., as described by Berns \& Thomas, 1965). The 
nucleic acids were precipitated from the lysate with ethanol, and were dissolved in SSC. DNA was partially purified by methods described earlier (Catlin \& Cunningham, 1964), and the concentration was determined by the diphenylamine reaction.

Competent cultures of strain RD. The use of Nephelos Flasks (Bellco Glass, Inc. Vineland, N.J.) containing $25 \mathrm{ml}$. volumes of broth permitted rapid periodic readings of extinction at $650 \mathrm{~m} \mu$ without risk of contaminating the growing cultures. Warmed $\mathrm{BHI}+\mathrm{HD}$ broth was inoculated with bacteria from an overnight culture to give

Table I. Strains of Haemophilus influenzae

\begin{tabular}{|c|c|c|c|c|}
\hline Strain & Use & $\begin{array}{l}\text { Appearance } \\
\text { of } \\
\text { colony }\end{array}$ & $\begin{array}{l}\text { Distribution and } \\
\text { origin of type } b \\
\text { antigen }\end{array}$ & $\begin{array}{l}\text { Response to } \\
\text { streptomycin } \\
(500 \mu \mathrm{g} . / \mathrm{ml} .)\end{array}$ \\
\hline $\mathbf{R D}$ & Recipient & $\begin{array}{l}\text { Non-iridescent, } \\
\text { moist, grayish } \\
\text { translucent }\end{array}$ & Absent & $\begin{array}{l}\text { Susceptible } \\
(3 \mu \mathrm{g} . \text { streptomycin/ } \\
\text { ml. inhibits growth) }\end{array}$ \\
\hline $\begin{array}{l}\text { SB smiriooo } \\
\text { (Santo) }\end{array}$ & $\begin{array}{l}\text { Source of DNA } \\
\text { preparation I ; } \\
\text { antigen for } \\
\text { immunization }\end{array}$ & $\begin{array}{l}\text { Iridescent, } \\
\text { opaque }\end{array}$ & $\begin{array}{l}\text { Present as capsule: } \\
\text { spinal fluid isolate }\end{array}$ & Resistant \\
\hline $\begin{array}{l}\text { MCH93 I I, type b } \\
\text { str-r }\end{array}$ & $\begin{array}{l}\text { Source of DNA } \\
\text { preparation } 2\end{array}$ & $\begin{array}{l}\text { Iridescent, } \\
\text { opaque }\end{array}$ & $\begin{array}{l}\text { Present as capsule: } \\
\text { spinal fluid isolate; } \\
\text { see Pl. I, fig. I }\end{array}$ & $\begin{array}{l}\text { Resistant, by single- } \\
\text { step mutation }\end{array}$ \\
\hline $\mathrm{RD}(93$ I I ) str-r $\mathrm{R}$ & FTA-staining & $\begin{array}{l}\text { Non-iridescent, } \\
\text { very rough, } \\
\text { greyish, opaque }\end{array}$ & $\begin{array}{l}\text { Present as patches, } \\
\text { not entire capsule; } \\
\text { see Pl. } 6\end{array}$ & $\begin{array}{l}\text { Resistant, by } \\
\text { transformation }\end{array}$ \\
\hline $\mathrm{RD}(\mathrm{b}) s t r-r$ & $\begin{array}{l}\text { Source of DNA } \\
\text { preparation } 3\end{array}$ & $\begin{array}{l}\text { Iridescent, } \\
\text { opaque }\end{array}$ & $\begin{array}{l}\text { Present as capsule: } \\
\text { transformant elicited } \\
\text { by DNA preparation }\end{array}$ & $\begin{array}{l}\text { Resistant, by single- } \\
\text { step mutation }\end{array}$ \\
\hline $\mathrm{RD}(\mathrm{b}) \mathrm{FA} s t r-r$ & $\begin{array}{l}\text { Source of DNA } \\
\text { preparation } 4\end{array}$ & $\begin{array}{l}\text { 'Faded' iri- } \\
\text { descent, slightly } \\
\text { translucent }\end{array}$ & $\begin{array}{l}\text { Present as capsule: } \\
\text { transformant elicited } \\
\text { by DNA preparation } \\
\text { 3; see Pl. I, fig. } 2\end{array}$ & $\begin{array}{l}\text { Resistant, by single- } \\
\text { step mutation }\end{array}$ \\
\hline $\mathrm{RD}(\mathrm{b}) \mathrm{BR} s t r-r$ & $\begin{array}{l}\text { Source of DNA } \\
\text { preparation } 5\end{array}$ & $\begin{array}{l}\text { 'Bright' } \\
\text { iridescent, } \\
\text { opaque }\end{array}$ & $\begin{array}{l}\text { Present as capsule: } \\
\text { transformant elicited } \\
\text { by DNA preparation } \\
\text { 3; see Pl. I, fig. } 3\end{array}$ & $\begin{array}{l}\text { Resistant by single- } \\
\text { step mutation }\end{array}$ \\
\hline
\end{tabular}

an initial extinction $0.060-0.090$. The flask was shaken at $37^{\circ}$ until the extinction reached $0.400-0.600$; the generation time was about $35 \mathrm{~min}$. Then the flask was tilted so that the culture ran into the side-arm (cuvette) where it was held at $37^{\circ}$ for $75 \mathrm{~min}$. (non-aerated period). Lastly the culture was tilted back into the flask and shaken at $37^{\circ}$ for $30 \mathrm{~min}$, at which time the bacteria numbered $3-6 \times 10^{9}$ colony-forming units $/ \mathrm{ml}$. Warm glycerol was added to give a concentration of $15 \%(\mathrm{v} / \mathrm{v})$, and the culture was distributed into $8 \mathrm{ml}$. screw-cap tubes and frozen at minus $60^{\circ}$.

Transformation tests. A tube of competent culture of strain RD was thawed at $37^{\circ}$ and immediately diluted $\mathrm{I} / 5$ in $\mathrm{BHI}+\mathrm{HD}$ broth or in double-strength Levinthal broth. The diluted culture was drawn up into a pipette and rapidly expelled, and this was repeated about 20 times to decrease cellular aggregation; one volume was then added to one volume of pre-warmed DNA solution (diluted in BHI + HD). The moment of mixing bacteria with DNA was taken as time zero; thereafter, the mixture was incubated in a water bath at $36.5^{\circ}$. After $20-30 \mathrm{~min}$. deoxyribonuclease 
(crystalline, Worthıngton Biochemical Corp.) was added to give a concentration of Io $\mu \mathrm{g}$. $/ \mathrm{ml}$. (details in Catlin, 1960). Samples were removed periodically for assays of transformation to capsular synthesis and to streptomycin resistance. Suitably diluted bacteria were spread over the surfaces of DHS-containing HIY + HD hard agar for kinetic studies of phenotypic expression. For other studies involving the str-r marker, bacteria were taken from broth about $30 \mathrm{~min}$. after time zero. A dilution was inoculated into a $20 \mathrm{ml}$. volume of DHS-free soft agar at $44^{\circ}$, and $4 \mathrm{ml}$. samples of the mixture were immediately pipetted on supporting layers of hard agar $(20 \mathrm{ml}$. volumes, pre-dried); after $5 \mathrm{~min}$. the plates were transferred to a $36^{\circ}$ incubator. The transformants were challenged $3.5 \mathrm{hr}$ after time zero by adding the antibiotic in a top layer $(6 \mathrm{ml}$. of soft agar containing $2500 \mu \mathrm{g}$. DHS/ml. to give a final concentration of $500 \mu \mathrm{g} . / \mathrm{ml}$.). Similarly in each test the number of colony-forming units $/ \mathrm{ml}$. of recipient bacteria was assayed in DHS-free agar. A control test with deoxyribonucleaseinactivated DNA was included in every experiment. Colonies were counted after incubation of plates for $2-3$ days.

Microscopic preparations. For the semi-quantitative assay of capsulated bacteria in a transformation reaction culture, $5 \mu \mathrm{l}$. (delivered with a Drummond Microcap, Kensington Sci. Corp., Oakland, Cal.) was spread uniformly on a clean microscope slide (0.96-I.06 mm. thickness) and dried. For tests of microcolony-formation, a loopful of the DNA-treated bacteria was spread on the surface of HIY + HD or Levinthal agar. After incubation for $\mathrm{I}-5 \mathrm{hr}$, a $2 \mathrm{~cm}$. square block of agar was cut out and inverted on a cleaned slide; the agar was immediately flipped off leaving a film which dried rapidly and maintained the spatial arrangements of the bacteria.

Films were fixed by immersion in absolute methanol for 10 min. soon after preparation and preferably stained the same day; but when this was impracticable they were stored in a tightly covered box in the refrigerator. Slides were never blotted, but were dried by evaporation. Staining was done by the method recommended by Cherry et al. (1960) and Biegeleisen et al. (1965). The FTA reagent was applied for $30 \mathrm{~min}$., poured off and the slide was rinsed for $5 \mathrm{~min}$. in each of two baths of phosphate-buffered saline $(\mathrm{pH} 7 \cdot 2)$ followed by water. The preparation was dried and mounted with $\mathrm{pH} 7 \cdot 2$ buffered-glycerol under a no. I $22 \times 30 \mathrm{~mm}$. coverslip. Stained slides were refrigerated until examined. For assays of number of capsulated transformants, the smear was scanned with the oil-immersion objective for a period of exactly $30 \mathrm{~min}$. using a standard search pattern.

Fluorescence microscopy and photography. FTA-stained preparations were examined using a Leitz Labolux III fluorescence microscope equipped with a dark-field condenser D I-20. BG-38, BG-12, and OG-I filters were used. An Osram HBO 200 high-pressure mercury burner was used and, alternately, a low-voltage tungsten lamp, which was valuable for revealing artifacts or for assessing the possible significance of unusual forms observed with ultraviolet radiation. Photographs were made using a fluorite oil-immersion objective, NA I.32 with iris diaphram, and $\times 10$ eyepiece, with a Leitz MIKAS microattachment and camera for $35 \mathrm{~mm}$. film. Kodak Tri-X film was developed in UFG developer at $21^{\circ}$ for $6 \frac{1}{4} \mathrm{~min}$. 


\title{
RESULTS
}

\section{Transforming activities of DNA preparations}

The response of one competent population to various DNA preparations is given in Table 2. DNA preparations 3-5, extracted from capsular transformants of strain $\mathrm{RD}$, were more active than DNAs from the clinical isolates. DNA preparation I, which we used for developmental work on the capsular transformation method, characteristically elicited the fewest capsules.

\section{Table 2. Transformation of Haemophilus influenzae strain $R D$ by deoxyribonucleate preparation from different donors}

\begin{abstract}
Mixtures of recipient bacteria, $3.7 \times 10^{8} / \mathrm{ml}$, and DNA in Levinthal broth were incubated at $36.5^{\circ}$; deoxyribonuclease was added after $20 \mathrm{~min}$., and incubation was continued. Samples taken at $30-60 \mathrm{~min}$. were assayed by the agar-overlay technique to determine resistance to $500 \mu \mathrm{g}$. DHS $/ \mathrm{ml}$; $5 \mu \mathrm{l}$. samples were taken at $\mathrm{I} 50 \mathrm{~min}$. for microscopic
\end{abstract} preparations (see Methods).

\begin{tabular}{|c|c|c|c|}
\hline \multirow[b]{2}{*}{ DNA donor strain } & \multirow{2}{*}{$\begin{array}{l}\text { DNA conc. } \\
(\mu \mathrm{g} . / \mathrm{ml} .)\end{array}$} & \multicolumn{2}{|c|}{ Transformants } \\
\hline & & Str-r (no./ml.) & Capsular* \\
\hline SB sm 1000 (preparation I) & $\begin{array}{l}1.0 \\
0.01 \\
0.000 I\end{array}$ & $\begin{array}{r}4,184,000 \\
779,600 \\
8,750\end{array}$ & $\begin{array}{r}88 \\
26 \\
0\end{array}$ \\
\hline MCH 93 I I str-r (preparation 2) & $\begin{array}{l}1.0 \\
0.01 \\
0.0001\end{array}$ & $\begin{array}{r}4,487,000 \\
830,600 \\
7,790\end{array}$ & $\begin{array}{r}214 \\
2 I \\
0\end{array}$ \\
\hline $\mathrm{RD}$ (b) str-r (preparation 3) & $\begin{array}{l}I .0 \\
0.01 \\
0.000 I\end{array}$ & $\begin{array}{r}5,920,000 \\
794,000 \\
8,460\end{array}$ & $\begin{array}{r}152 \\
70 \\
0\end{array}$ \\
\hline RD(b)FA str-r (preparation 4) & $\begin{array}{l}I .0 \\
0.01 \\
0.000 I\end{array}$ & $\begin{array}{r}5,014,000 \\
714,500 \\
8,650\end{array}$ & $\begin{array}{r}275 \\
29 \\
0\end{array}$ \\
\hline RD(b)BR str-r (preparation 5) & $\begin{array}{l}1.0 \\
0.01 \\
0.0001\end{array}$ & $\begin{array}{r}5,504,000 \\
678,000 \\
7,330\end{array}$ & $\begin{array}{r}165 \\
50 \\
1\end{array}$ \\
\hline
\end{tabular}

* Number counted during a 30 min. period of standard search.

The assay technique for capsulated bacteria is only semi-quantitative. Although the microscopic preparation contained all the transformants present in a $5 \mu \mathrm{l}$. sample, some of these would not be counted during the allotted time. Nevertheless, the counts indicate that, under these test conditions, the frequency of transformation to capsular synthesis was only about $\mathrm{I} \%$ that to streptomycin resistance. In pneumococcus, also, the ratio of type I capsular transformants to str-r transformants is about I \% (Bernheimer et al. 1967). However, this apparent concordance may be accidental as the methods differ significantly in respect to the stage at which transformation is detected. In the pneumococcal system capsular transformants are recognized only after they have undergone considerable multiplication; any which are unable to divide normally may be overlooked. In the Haemophilus influenzae system the genetic event is detected at the cellular level, and within $2 \mathrm{hr}$. However, as will be shown in the next section, the multiplication of these newly capsulated bacteria was affected, and some may not have formed macrocolonies during subsequent incubation. 
Transformation to capsular synthesis was related to the concentration of DNA (Table 2), and capsulated bacteria were never found in control preparations of recipient strain RD treated with deoxyribonuclease-inactivated DNA. The response of competent bacteria to eight different concentrations of DNA was examined in experiments with DNA preparations 2 and 4. Results for both str-r and type b antigen markers corresponded to those for streptomycin resistance reported by Alexander, Leidy \& Hahn (1954) and by Goodgal (I96I). Capsulated bacteria were observed in tests of $0.000 \mathrm{I} \mu \mathrm{g}$. DNA $/ \mathrm{ml}$, , and the number rose in proportion to the concentration up to about $0.1 \mu \mathrm{g}$. DNA $/ \mathrm{ml}$. A ten-fold higher DNA concentration elicited only a $20-25 \%$ increase of capsulated forms.

\section{Phenotypic expression}

To examine the kinetics of capsular transformation of strain RD, and to permit comparisons with another genetic marker, periodic samples of a recipient population cultivated in broth continuously for $5.5 \mathrm{hr}$ were tested. After treatment with $\mathrm{I} \cdot 0 \mu \mathrm{g}$. DNA $/ \mathrm{ml}$. for $20 \mathrm{~min}$., deoxyribonuclease was added. Total number of bacteria, number of bacteria resistant to DHS $(200 \mu \mathrm{g} . / \mathrm{ml}$. and $500 \mu \mathrm{g} . / \mathrm{ml}$.) and number of capsulated bacteria were determined. Three different DNA preparations (2, 4 and 5$)$ were examined in similar experiments.

Figure I shows the time course of the increase of streptomycin-resistant transformants and of the total population (generation time about $50 \mathrm{~min}$. during the first $2 \mathrm{hr}$ ) after adding DNA (preparation 5) from the transformant strain $\mathrm{RD}(\mathrm{b}) \mathrm{BR}$ $s t r-r$. No transformants were found after treatment for $5 \mathrm{~min}$. Beginning at about $25 \mathrm{~min}$. there was an initial rapid increase in numbers of bacteria which were able to form colonies when spread directly on DHS-containing agar. About $7 \times 10^{6} \mathrm{str}-\mathrm{r}$ transformants per $\mathrm{ml}$. were present after incubation of the original reaction mixture for $145 \mathrm{~min}$. Thereafter, the rate of increase of the str-r transformants was about the same as that of the total population (doubling times 70-75 min. over the period 145-220 min.).

During the early stages of expression of the streptomycin-resistant phenotype, transformants were not equally resistant to DHS. Alexander \& Leidy (I953) had found that resistance to $10 \mu \mathrm{g}$. streptomycin $/ \mathrm{ml}$. began to develop within $15 \mathrm{~min}$., but that resistance to $1000 \mu \mathrm{g} . / \mathrm{ml}$. appeared only after some delay. In our tests (Fig. I) new transformants which had become resistant to $200 \mu \mathrm{g}$. DHS $/ \mathrm{ml}$. appeared to require about $5 \mathrm{~min}$. to increase their resistance to $500 \mu \mathrm{g} . / \mathrm{ml}$. Thus, in $\mathrm{I} \cdot 0 \mathrm{ml}$. of the $30 \mathrm{~min}$. sample, I420 transformants produced colonies on agar containing $200 \mu \mathrm{g} . / \mathrm{ml}$., but only I 80 grew out on $500 \mu \mathrm{g} . / \mathrm{ml}$.; whereas in the $35 \mathrm{~min}$. sample, I4IO were resistant to $500 \mu \mathrm{g} . / \mathrm{ml}$. This intervening time may be required for a stage in the modification of ribosomes (Luzzatto, Apirion \& Schlessinger, 1968; Stuart \& Ravin, I968). Bacteria sampled after I 20 min. incubation no longer showed a significant difference of degree of resistance, which suggested that phenotypic expression was essentially complete at this time. This was corroborated by the sharp deflection of the curve representing increase of str-r transformants which occurred regularly at I20-I45 min. in each of three experiments. Furthermore, a subculture of the original reaction mixture diluted $I / 20$ in fresh pre-warmed broth to stimulate continued multiplication showed similar growth rates of str-r transformants and total bacteria (open symbol-curves Fig. I). 
The time course of phenotypic expression of capsulation during incubation of broth cultures could not be followed with the same precision as streptomycin resistance because of the lower reproducibility inherent in the method of preparing and scanning the microscope slide preparations. In six different experiments samples were taken at $5 \mathrm{~min}$. intervals over the period 35 to $60 \mathrm{~min}$., and the FTA-stained preparations

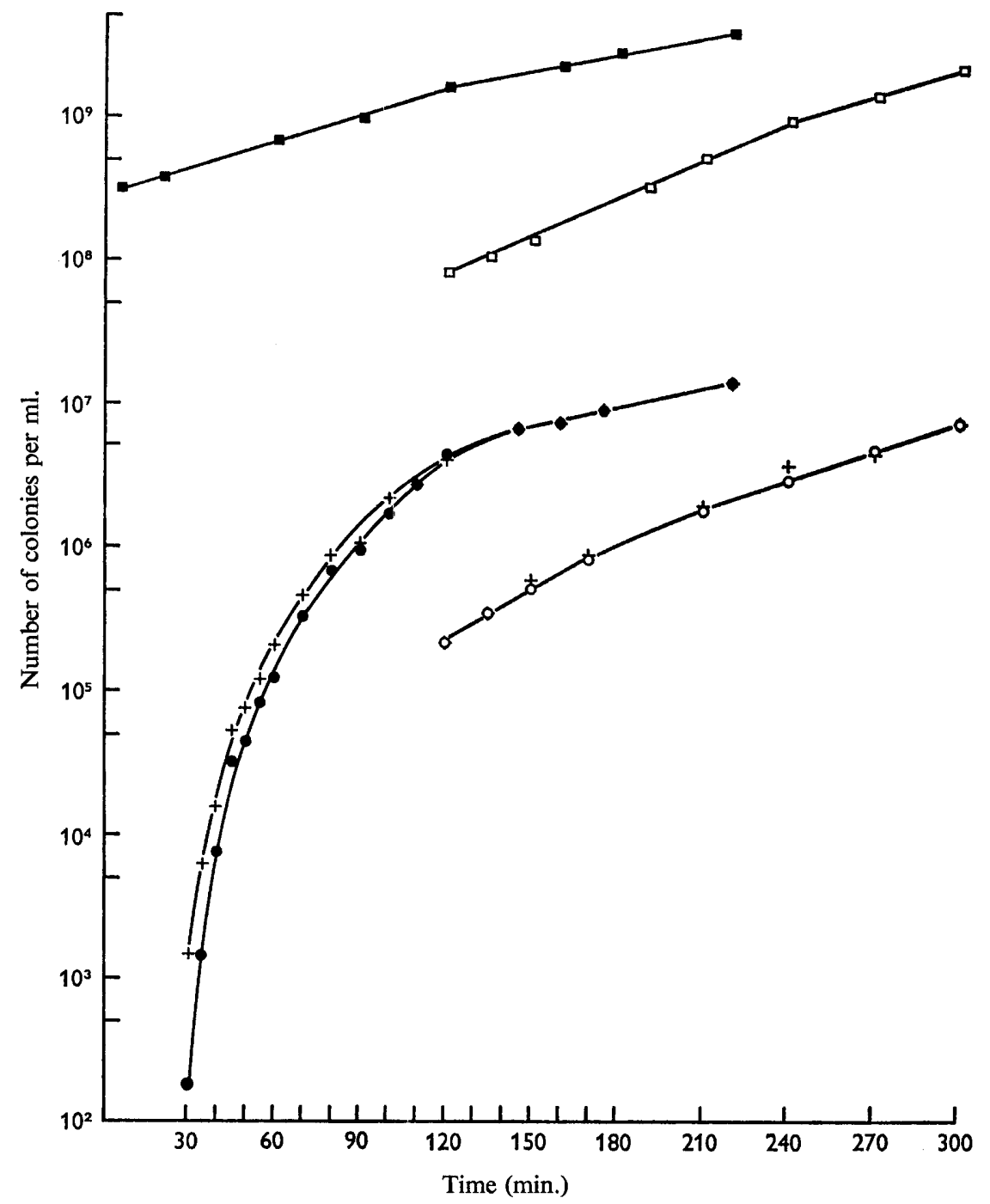

Fig. I. Increase of streptomycin-resistant transformants and of the total population during cultivation in $\mathrm{BHI}+\mathrm{HD}$ broth of strain RD treated with $\mathrm{I} \cdot 0 \mu \mathrm{g}$. DNA preparation $5 / \mathrm{ml}$. Deoxyribonuclease was added after $20 \mathrm{~min}$. A subculture representing a $\mathrm{I} / 20$ dilution of the original culture was made after $120 \mathrm{~min}$. Symbols: $\boldsymbol{\square}$, colonies on DHS- free agar plated with sample of the undiluted culture; $\square$, colonies on DHS-free agar plated with sample of the diluted culture; + (left-hand curve), colonies on agar containing $200 \mu \mathrm{g}$. DHS $/ \mathrm{ml}$. from undiluted culture; + (right-hand curve), colonies on agar containing $200 \mu \mathrm{g}$. $\mathrm{DHS} / \mathrm{ml}$. from diluted culture; $\odot$, colonies on agar containing $500 \mu \mathrm{g}$. DHS $/ \mathrm{ml}$. plated with sample of the undiluted culture; $O$, colonies on agar containing $500 \mu \mathrm{g}$. DHS $/ \mathrm{ml}$. plated with sample of the diluted culture. 
were each examined systematically for one or two $30 \mathrm{~min}$. periods of the standard search. Fluorescent capsules were first detected 40 and $50 \mathrm{~min}$. after exposure to DNA preparation 2, 40 and $45 \mathrm{~min}$. after exposure to DNA 4, and 45 and $50 \mathrm{~min}$. after exposure to DNA 5. Cultures then showed a progressive, though erratic, increase in number of capsulated bacteria over the next $75 \mathrm{~min}$. After I $20 \mathrm{~min}$. total elapsed time of incubation, phenotypic expression of capsulation was nearly complete. Thereafter, unlike the str-r transformants, the number of capsulated bacteria tended to remain approximately the same, within a two-fold range of experimental variation, during subsequent incubation for $3 \mathrm{hr}$. Figure 2 shows results of assays of the same population which was examined in Fig. I. Diluting the original culture after $120 \mathrm{~min}$. incubation (open circles) reduced the number of capsulated organisms found. Samples taken at the time of preparation of this subculture yielded 186 for the undiluted culture and 2.5 for the $1 / 20$ dilution. In subsequent samples the number of capsulated organisms in the diluted culture fluctuated within the range 14 to 44 , and within the range I 8 to 225 for the parallel undiluted culture. These values represent capsulated units; the bacteria present in an unseparated pair or chain were counted as one because of difficulties of interpretation (for example, Pl. 3, fig. 24, 25, 30-38). Their number was tallied, however, and did not exceed $15 \%$ of the number of single capsulated bacteria. In contrast, a few transformants began to multiply normally during this period, as revealed by rare microcolonies containing 9 to 16 capsulated bacteria on impression smears of $4 \mathrm{hr}$ agar cultures (Pl. 2, fig. I2). The data, however, show only a minor tendency for replication of the capsulated bacteria, as opposed to the replication of str-r transformants.

Corresponding results, though with a lower yield of transformants, were obtained in a similar experiment performed with DNA (preparation 2) from a type b clinical isolate. As before, str-r transformants were unequally resistant to DHS during the early stages of expression. Thus, the $35 \mathrm{~min}$. sample contained I040 transformants $/ \mathrm{ml}$. resistant to $200 \mu \mathrm{g}$. DHS $/ \mathrm{ml}$., but only $240 / \mathrm{ml}$. resistant to $500 \mu \mathrm{g} . / \mathrm{ml}$.; $5 \mathrm{~min}$. later I050 transformants $/ \mathrm{ml}$. were resistant to $500 \mu \mathrm{g}$. $/ \mathrm{ml}$. After $120 \mathrm{~min}$. total incubation the transformants were equally resistant, and they numbered $2 \cdot 0 \times 10^{6} / \mathrm{ml}$. (compared to $4.6 \times 10^{6} / \mathrm{ml}$. for the experiment shown in Fig. 1 ); the total population at this time (both experiments) had reached $1 \cdot 7 \times 10^{9}$ colony-forming units $/ \mathrm{ml}$. The numbers of transformants to capsular synthesis found in samples of this culture and in a $1 / 20$ dilution are given in Fig. 3. They were lower than in the experiment plotted in Fig. 2, as expected from the lower frequency of str-r transformation elicited by this DNA. Too few capsulated bacteria were present in the diluted culture for accurate counts, which ranged from 8 down to zero for samples taken at 180 and $300 \mathrm{~min}$. However, they confirm the previous finding of minimal increase.

Thus, the transforming DNA initiated the process of synthesis of type b antigen, but multiplication of many of these newly capsulated bacteria was arrested. In view of their failure to divide during this $5.5 \mathrm{hr}$ period of incubation, and the possibility that some may not subsequently produce macrocolonies, they will be referred to as capsular 'transformants' in the following discussion.

\section{Properties of capsular 'transformants'}

We originally supposed that the processes of initiating competence and freezing and thawing might partially synchronize the bacteria such that, after a limited 
exposure to transforming DNA, the sites of initiation of capsule production might be revealed in newly transformed bacteria. Actually, transitional forms were rare. A few non-capsulated bacteria in samples taken after 35 to $50 \mathrm{~min}$. incubation exhibited polar or subpolar dots, one or more rarely two per organism. Although their fluorescence was stronger than that of the weakly stained wall, the intensity was insufficient for photography. Most early capsules were entire but narrow, and stained with only moderate brilliance (e.g. Pl. 3, fig. 15, 16, 25, 26 and Pl. 4, fig. 46, 47).

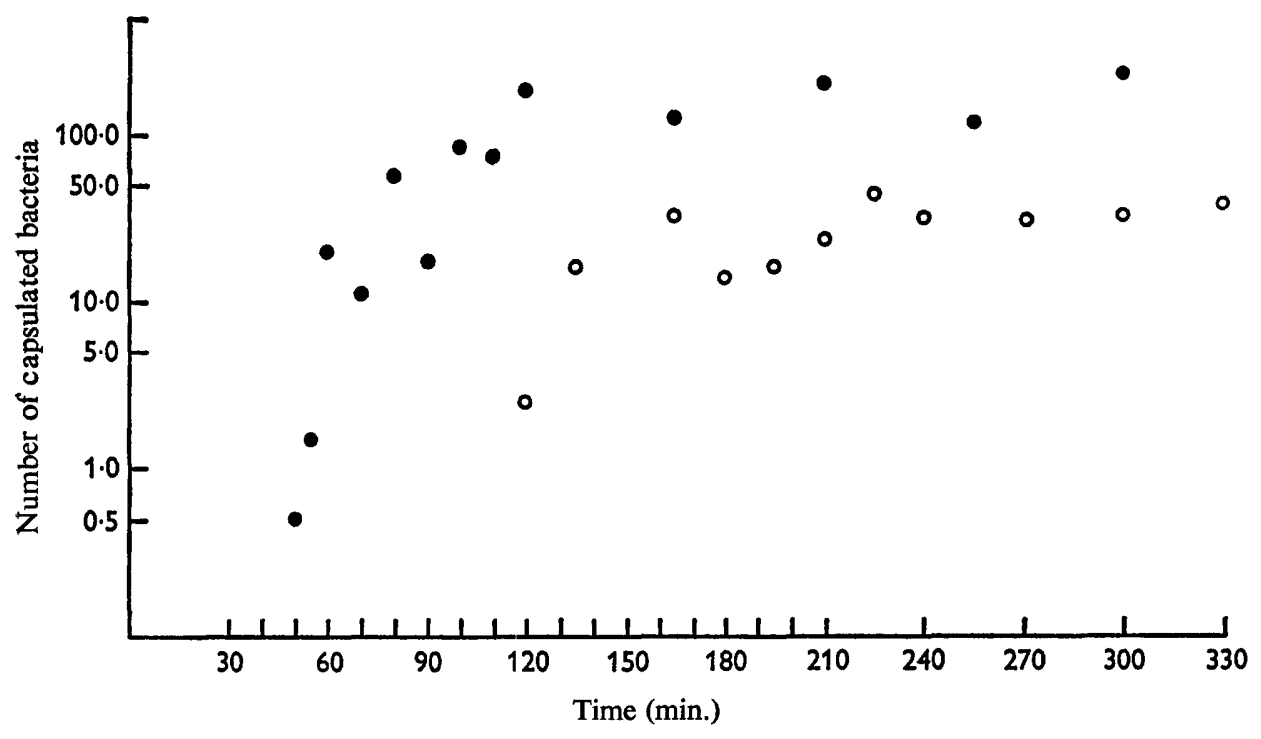

Fig. 2. Capsulated bacteria found during incubation of the undiluted $(\bullet)$ and the diluted $(O)$ transformation cultures of the experiment shown in Fig. I.

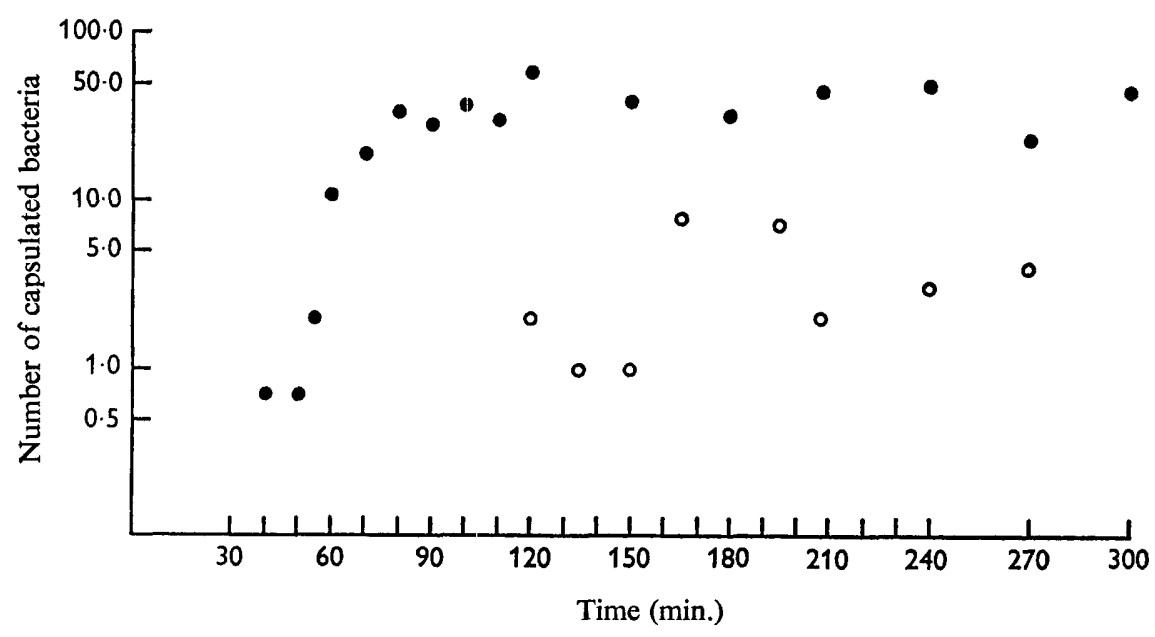

Fig. 3. Transformants to capsular synthesis found during cultivation in BHI + HD broth of strain RD which was treated with $\mathrm{I} \cdot 0 \mu \mathrm{g}$. DNA preparation $2 / \mathrm{ml}$. Deoxyribonuclease was added after $20 \mathrm{~min}$. A subculture representing a $\mathrm{I} / 20$ dilution of the original culture was made after 120 min. Symbols: $\bullet$, capsulated bacteria in undiluted culture; $O$, capsulated bacteria in diluted culture. 
During phenotypic expression, and subsequently, the capsular 'transformants' showed considerable morphological diversity. As each represented the culmination of a separate genetic event, it is premature now to attempt to reconstruct a sequence of events based on observations of forms in successive samples of a transformation culture. Accordingly, photographs are presented to document this diversity.

A few of the capsular 'transformants' multiplied to produce pairs or short chains of bacteria, which tended to remain attached, even in preparations of broth cultures. Commonly their capsules fluoresced with unequal brilliance, suggesting a motherdaughter relationship (Pl. 2, fig. IO; Pl. 3, fig. 23-25, 3I). Other 'transformants' which had undergone growth without division showed similar inequalities of capsule production (Pl. 3, fig. 35-37; Pl. 5, fig. 62, 66). Some filamentous forms were entirely capsulated (PI. 4, fig. 56), but others were not (Pl. 4, fig. 42, shows a dispersion of capsular material). Still other 'transformants' were observed in which capsular synthesis had diminished or had ceased altogether, while growth and wall-formation continued; these showed a polar or bipolar conservation of the capsule (e.g. Pl. 4, fig. $44-45,5 \mathrm{I}-53$; Pl. 5, fig. 72-73).

A pair of bacteria of which only one was capsulated was seen in a 70 min. sample (Pl. 4, fig. 48-49). As the total number of bacteria had more than doubled at this time, different interpretations are possible. The DNA might have altered only one of two 'chromosomes' present in a single competent bacterium, and at division these were segregated into separate bacteria. Or, the DNA may have entered one bacterium of a pre-existing pair; it was earlier recognized that in the competent population a colony-forming unit is composed of between 1.6 and 2 bacteria (Goodgal \& Herriott, 1961). Another possibly similar example, observed after longer incubation (Pl. 4, fig. 43), was a chain composed of multiple unseparated capsulated and non-capsulated units.

Among the capsular 'transformants' elicited by DNA (preparation 2) from a type b clinical isolate were forms (Io to $15 \%$ of the total) which showed bright fluorescent embossments which appeared to be incomplete capsules (Pl. 5). The DNA donor strain itself exhibited normal capsules (PI. I, fig. I), and young colonies on HIY + HD agar were highly iridescent when viewed with oblique transmitted light. However, the strain was genetically unstable, and upon further incubation, rough areas developed along the margins of some colonies. Subcultures of such areas produced very rough, non-iridescent colonies, as vividly described by Pittman (I93I). Smears of these R mutants revealed pleomorphic rods, some of which showed fluorescent embossments resembling those of the 'transformants' (and possibly similar to the forms noted by Sell et al. 1963). Furthermore, the same kind of non-iridescent very rough colonies arose during subculture of iridescent transformant colonies isolated from DNA preparation 2-reaction cultures.

The type $\mathrm{b}$ antigen of one such very rough isolate (designated RD(93I I) str-r $\mathrm{R}$; see Pl. 6) was synthesized according to specifications received from strain MCH93II. That the embossments were typically fluorescent suggested that the serological specificity of the type $b$ antigen was normal. However a more critical evaluation of the specificity of the FTA reaction could be made using the one-step fluorescenceinhibition test (Goldman, 1957). This was done on preparations of $5 \mathrm{hr}$ cultures of strain RD(93II) str-r R, and on the capsulated DNA donor strain and a rough variant derived from it. The fluorescence of all capsular antigen was greatly decreased in tests where the combining sites were blocked by unlabelled type $b$ antibody (from 
NCDC). Control preparations with undiluted normal rabbit serum substituted for the unlabelled antiserum in the mixture with the FTA reagent showed brilliant fluorescence of the embossments as well as of the capsules of the donor strain. Thus the identity of the fragmentary capsular material as type $b$ antigen was verified.

The capacity of these bacteria to produce type $b$ antigen was evidently dissociated from the capacity to produce an intact capsular structure. Another example of a genetic difference which affected the morphology of the capsule without altering the antigenic specificity of the capsular material was detected by differences of colonial iridescence. 'Bright' (BR) colonies were distinguished from FA colonies present in the same transformation reaction culture by a greater brilliance of iridescence observed with oblique transmitted light (Table I). The FTA-stained capsules of the BR colony transformants were typically more massive than those of the FA colony transformants (P1. I, fig. 2, 3), the distinction was more conspicuous with young cultures on agar than in broth, possibly owing to solubility of the capsular antigen (noted by Pittman, 193I). The genetic basis of these differences remains to be established.

\section{DISCUSSION}

The culture of non-capsulated streptomycin-susceptible recipient bacteria examined in the experiment presented in Fig. I and 2 had a generation time of about $50 \mathrm{~min}$. during the first $2 \mathrm{hr}$ of incubation. Str-r transformants began to appear $25 \mathrm{~min}$. after initiation of DNA treatment. Capsulated bacteria were observed at 40 to $50 \mathrm{~min}$., and for the next hour both kinds of transformant phenotypes continued to be expressed. Thereafter, the recipients of the two kinds of genetic markers differed in their behaviour. The rate of increase of str-r transformants after $2 \mathrm{hr}$ incubation became equal to that of the total recipient population. In contrast, the number of capsulated bacteria increased only slightly during incubation of the same culture over the period 120 to $330 \mathrm{~min}$; some became filamentous during this time signifying a disturbance of cellular division. Furthermore, although iridescent colonies composed of capsulated bacteria were present on assay plates, the number did not approach that expected on the basis of the estimated ratio of capsulated to str- $r$ transformants ( 0.1 to I.0\%).

An adequate interpretation of these observations in molecular terms will require further knowledge, including information on the question of whether or not the locus determining type $b$ antigen is integrated at this time. Integration of the str locus has been shown to occur soon after uptake of donor DNA by the RD strain of Haemophilus influenzae (Voll \& Goodgal, 196I ; Notani \& Goodgal, 1966). Explanations which may account for the two- to three-generation lag in multiplication of str-r transformants cannot be invoked for the much longer delay which we observed for the capsular 'transformants'. Not only were their replicative activities disturbed, but in many instances synthesis of type $b$ antigen apparently diminished or ceased. Plates 2 to 5 show examples of various capsular 'transformants' which had grown and synthesized new wall material without producing a corresponding amount of capsular antigen. These findings bear some resemblance to abortive transduction of Salmonella in which phage-introduced bacterial DNA fails to be integrated but persists as a functional, non-replicating fragment passing in a unilinear manner from the recipient to only one daughter bacterium at each division (see, Demerec \& Ozeki, 1959; Stocker, 1963). 
We thank Miss Grace Leidy for information and strains, and Miss Mary Nimlos for assistance with immunofluorescence techniques. This study was supported by Public Health Service grant AI 02353; V.T. was aided by a grant from the Marquette University Committee on Research. Part of this work was included in a thesis submitted by V.T. to the Graduate School, Marquette University, in partial fulfilment of the requirements for the M.S. degree.

\section{REFERENCES}

Alexander, H. E. (1965). The Hemophilus group. In Bacterial and Mycotic Infections of Man. Ed. by R. J. Dubos and J. G. Hirsch. Philadelphia: J. B. Lippincott Co.

AleXANDER, H. E. \& LeIDY, G. (I95I). Determination of inherited traits of $H$. influenzae by desoxyribonucleic acid fractions isolated from type-specific cells. J. exp. Med. 93, 345.

AlexANDer, H. E. \& LeIDY, G. (1953). Induction of streptomycin resistance in sensitive Hemophilus influenzae by extracts containing desoxyribonucleic acid from resistant Hemophilus influenzae. J. exp. Med. $97, \mathrm{I} 7$.

Alexander, H. E., Leidy, G. \& Hahn, E. (1954). Studies on the nature of Hemophilus influenzae cells susceptible to heritable changes by desoxyribonucleic acids. J. exp. Med. 99, 505.

Alexander, H. E., Leidy, G. \& MacPherson, C. (I946). Production of types a, b, c, d, e and $f$ $H$. influenzae antibody for diagnostic and therapeutic purposes. J. Immunol. 54, 207.

Austrian, R. (1952). Bacterial transformation reactions. Bact. Rev. 16, 3 I.

BerNheimer, H. P., WeRMUNDSEN, I. E. \& AUSTRIAN, R. (1967). Qualitative differences in the behavior of pneumococcal deoxyribonucleic acids transforming to the same capsular type. J. Bact. 93, 320.

Berns, K. I. \& Thomas, C. A. JUn. (1965). Isolation of high molecular weight DNA from Hemophilus influenzae. J. molec. Biol. Ir, 476.

Biegeleisen, J. Z., Marcus, B. B., Dawson, W. L. \& Cherry, W. B. (1965). Immunofluorescence technics for demonstrating bacterial pathogens associated with cerebrospinal meningitis. Appendix A. Preparation and laboratory testing of labeled globulins. From the U.S. Department of Health, Education, and Welfare. Public Health Service, Communicable Disease Center, Atlanta, Georgia.

Catlin, B. W. (1958). X factor for aerobic growth of H. influenzae. Microbial Genetics Bull. 16, 5.

Catlin, B. W. (1960). Transformation of Neisseria meningitidis by deoxyribonucleates from cells and from culture slime. J. Bact. 79, 579.

Catlin, B. W. \& Cunningham, L. S. (1964). Genetic transformation of Neisseria catarrhalis by deoxyribonucleate preparations having different average base compositions. J. gen. Microbiol. 37, 34I.

Cherry, W. B., Goldman, M., Carski, T. R. \& Moody, M. D. (1960). Fluorescent antibody techniques. Public Health Service Publication No. 729. Washington, D.C.: U.S. Government Printing Office.

CoLE, R. M. (1965). Symposium on the fine structure and replication of bacteria and their parts. III. Bacterial cell-wall replication followed by immunofluorescence. Bact. Rev. 29, 326.

Demerec, M. \& OZEKI, H. (I959). Tests for allelism among auxotrophs of Salmonella typhimurium. Genetics 44, 269.

Goldman, M. (1957). Staining Toxoplasma gondii with fluorescein-labeled antibody. II. A new serologic test for antibodies to Toxoplasma based upon inhibition of specific staining. $J$. exp. Med. 105, 557.

GoodGal, S. H. (196I). Studies on transformations of Hemophilus influenzae. IV. Linked and unlinked transformations. J. gen. Physiol. 45, 205.

Goodgal, S. H. \& Herrotr, R. M. (I96I). Studies on transformations of Hemophilus influenzae. I. Competence. J. gen. Physiol. 44, 1201.

Gordon, M. A., EDwards, M. R. \& Tompkins, V. N. (1962). Refinement of fluorescent antibody by gel filtration. Proc. Soc. exp. Biol. Med. ro9, 96.

KoHN, J. (I959). A simple method for the concentration of fluids containing proteins. Nature, Lond. I83, 1055 . 
Leidy, G., Hahn, E. \& AleXander, H. E. (1953). In vitro production of new types of Hemophilus influenzae. J. exp. Med. 97, 467.

Leidy, G., JAFFEE, I. \& AleXANDER, H. E. (1962). Emergence of competence (for transformation) of three Hemophilus species in a chemically defined environment. Proc. Soc. exp. Biol. Med. III, 725.

Leidy, G., Hahn, E., ZamenhoF, S. \& AleXander, H. E. (I960). Biochemical aspects of virulence of Hemophilus influenzae. Ann. N.Y. Acad. Sci. 88, i 195.

Luzzatto, L., Apirion, D. \& Schlessinger, D. (1968). Mechanism of action of streptomycin in E. coli: interruption of the ribosome cycle at the initiation of protein synthesis. Proc. natn. Acad. Sci. U.S.A. 60, 873.

Notani, N. \& GoOdGal, S. H. (1966). On the nature of recombinants formed during transformation in Hemophilus influenzae. J. gen. Physiol. 49 (Part 2), 197.

Pittman, M. (1931). Variation and type specificity in the bacterial species Hemophilus influenzae. J. exp. Med. 53, 471 .

Ravin, A. W. (1954). A quantitative study of autogenic and allogenic transformations in pneumococcus. Expl Cell Res. 7, 58.

Rosenberg, E. \& ZAMENHOF, S. (1961). Further studies on polyribophosphate. J. biol. Chem. 236, 2845.

SCHAeffer, P. (1964). Transformation. In The Bacteria, Vol. 5. Ed. by I. C. Gunsalus and R. Y. Stanier. N.Y.: Academic Press Inc.

Sell, S. H. W., Cheatham, W. J., Young, B. \& Welch, K. (1963). Hemophilus influenzae in respiratory infections. Am. J. Dis. Child. I05, 466.

SPENCER, H. T. \& HeRriotT, R. M. (1965). Development of competence of Haemophilus influenzae. J. Bact. 90, 9 II .

STOCKeR, B. A. D. (1963). Transformation of Bacillus subtilis to motility and prototrophy: micromanipulative isolation of bacteria of transformed phenotype. J. Bact. 86, 797.

Stuart, J. J. \& Ravin, A. W. (1968). Levels of resistance in ribosomes from genetically linked, streptomycin-resistant mutants of pneumococcus. J. gen. Microbiol. 5I, 411 .

StUY, J. H. (1962). Transformability of Haemophilus influenzae. J. gen. Microbiol. 29, 537.

Voll, M. J. \& GoodGal, S. H. (196I). Recombination during transformation in Hemophilus influenzae. Proc. natn. Acad. Sci. U.S.A. 47, 505.

\section{EXPLANATION OF PLATES}

Photomicrographs of Haemophilus influenzae preparations stained with fluorescein isothiocyanateconjugated anti-type b globulin. Ultraviolet (u.v. 20 to 45 sec. exposure) or tungsten light ( 60 to $65 \mathrm{sec}$. exposure) was used with a dark-field condenser. Magnification of all bacteria approximately $\times 2900$.

\section{Plate I}

Fig. I-3. Pure cultures of DNA-donor strains incubated $6.5 \mathrm{hr}$ on HIY + HD agar. U.v., $25 \mathrm{sec}$. Fig. I, MCH 931 I type b str-r, source of DNA 2. Fig. 2, RD(b)FA str-r, source of DNA 4. Fig. 3, $\mathrm{RD}(\mathrm{b}) \mathrm{BR}$ str-r, source of DNA 5.

Fig. 4-7. Capsular 'transformants' in impression preparations; strain RD was treated 30 min. with DNA $5,1 \cdot 5 \mu \mathrm{g} . / \mathrm{ml}$, and subsequently incubated on HIY + HD agar. Fig. 4, 5, Iro min. total incubation, u.v. $30 \mathrm{sec}$. Fig. 6, $225 \mathrm{~min}$. total incubation; bacteria photographed with u.v., $25 \mathrm{sec}$.; Fig. 7, tungsten exposure of the same bacteria shows that peripheral notches of the voluminous capsules are deformations due to the abutting non-capsulated bacteria (RD recipients whose margins appear bright due to dark-field illumination).

Plate 2

Fig. 8-14. Capsular 'transformants' in impression preparations; strain RD was treated 30 min. with DNA $4, \mathrm{I} \cdot 5 \mu \mathrm{g}$. $/ \mathrm{ml}$, and subsequently incubated on HIY + HD agar. Fig. 8, $105 \mathrm{~min}$. total incubation; bacteria photographed with u.v., $40 \mathrm{sec}$.; Fig. 9, tungsten exposure of the same bacteria shows the capsulated organism located in the corresponding position together with non-capsulated (dark-field illuminated) forms. Fig. 10, $210 \mathrm{~min}$. total incubation; bacteria photographed with u.v., $35 \mathrm{sec}$; Fig. II, tungsten exposure of the same bacteria shows that crowding by non-capsulated bacteria is responsible for the notched margin of the capsule at right, but not for the different intensity of 
Journal of General Microbiology, Vol. 56, No. 3

Plate I
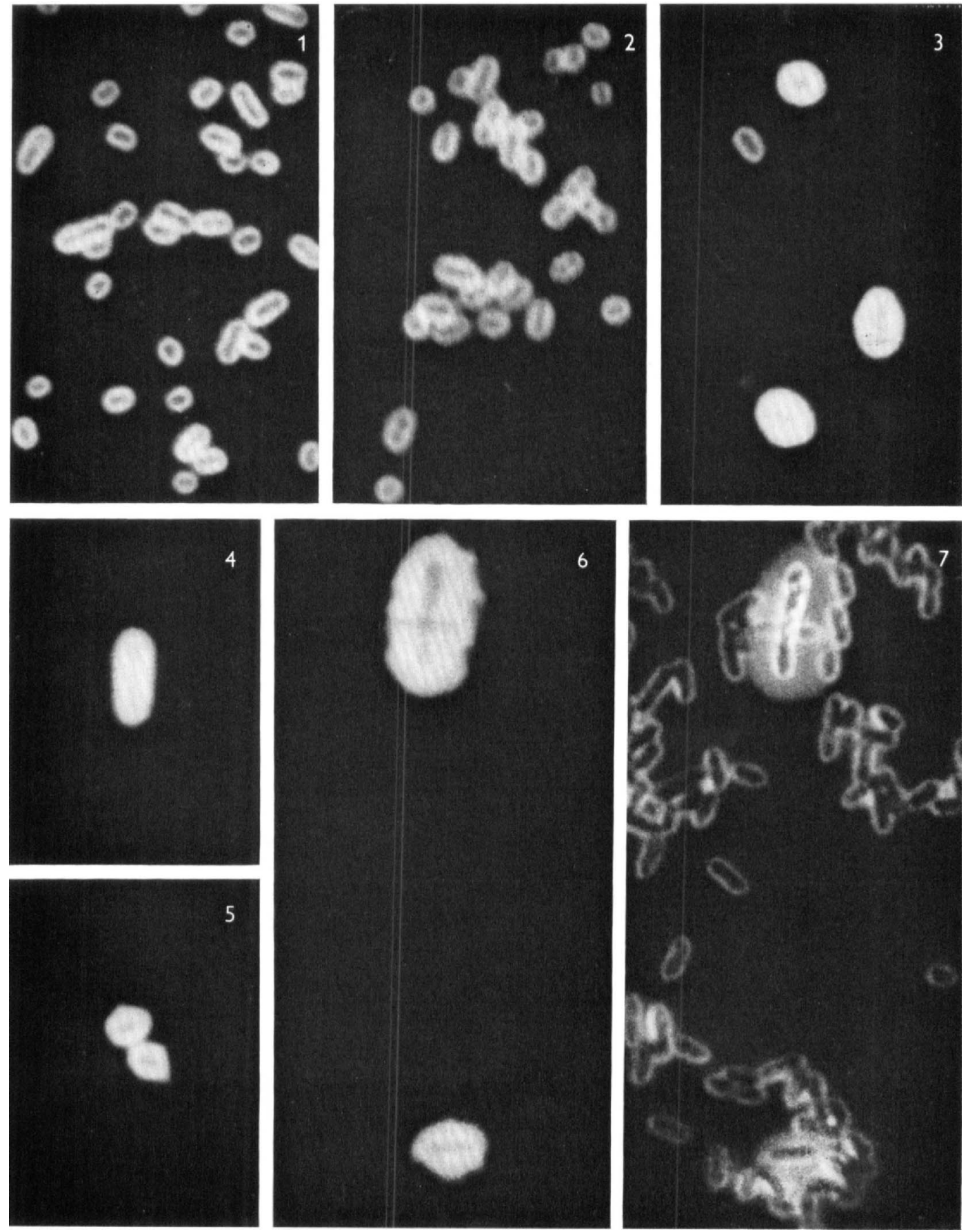

B. W. CATLIN AND V. R. TARTAGNI

(Facing p. 400) 
Journal of General Microbiology, Vol. 56, No. 3

Plate 2
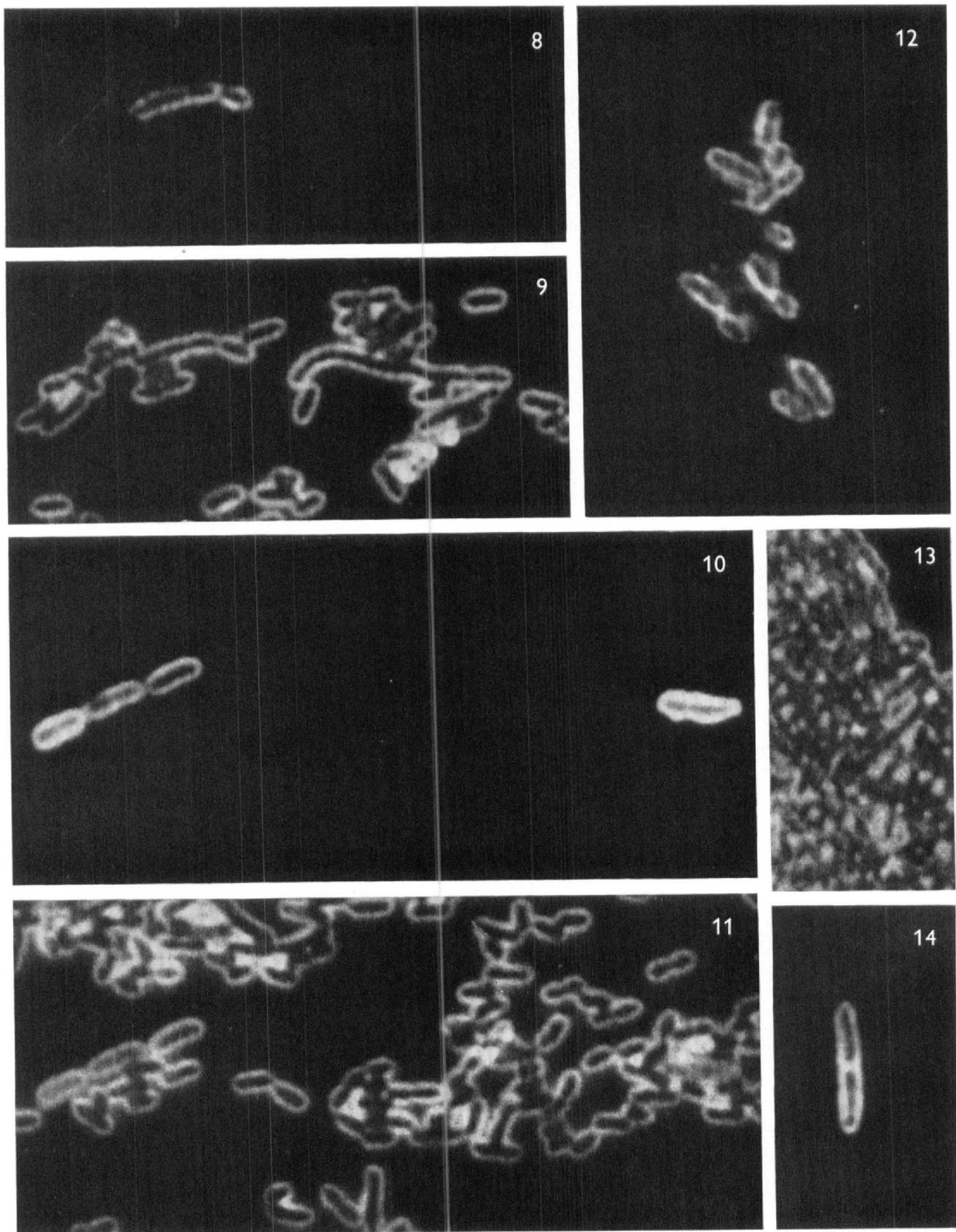

B. W. CATLIN AND V. R. TARTAGNI 
Journal of General Microbiology, Vol. 56, No. 3

Plate 3
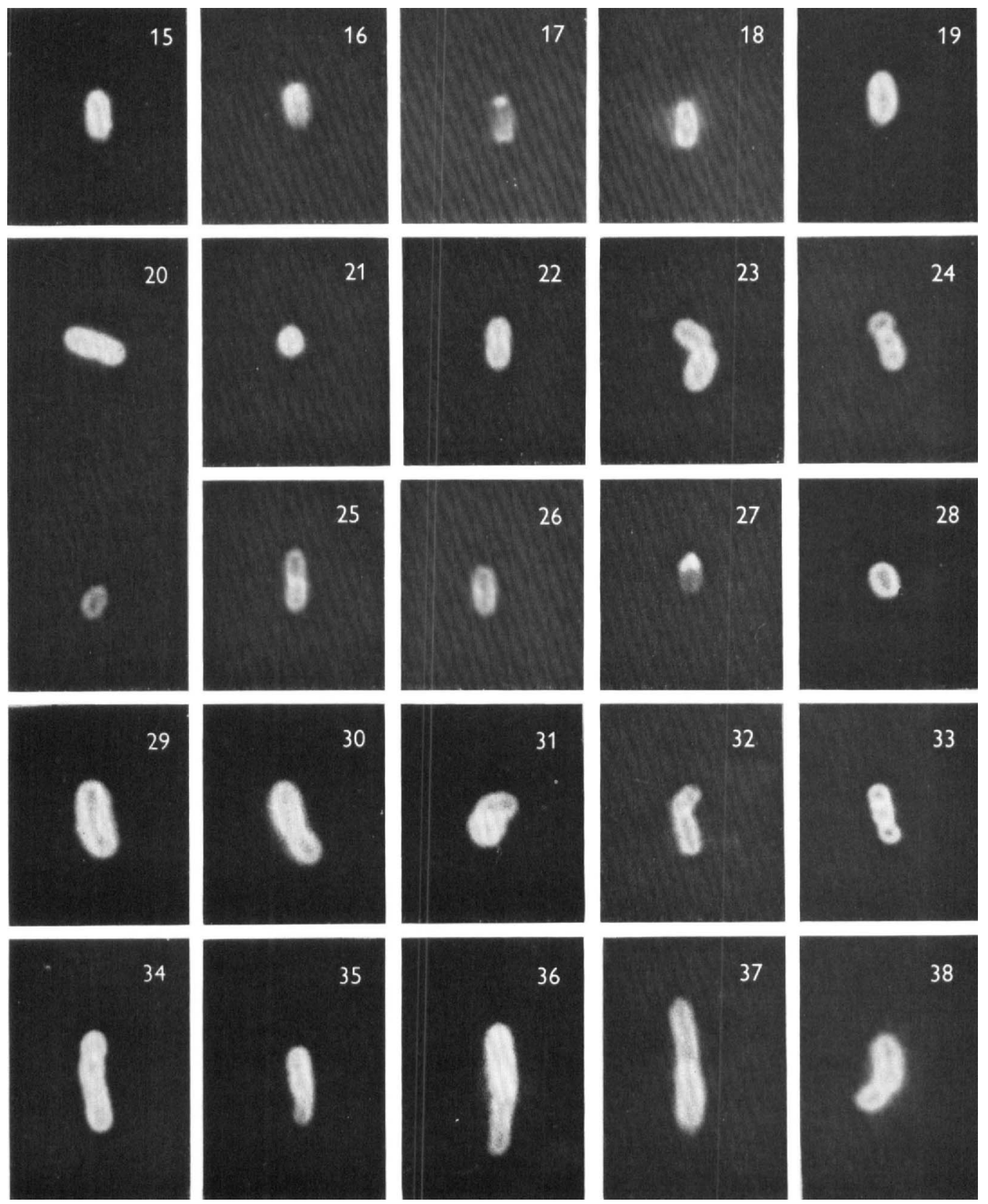

B. W. CATLIN AND V. R. TARTAGNI 
Journal of General Microbiology, Vol. 56, No. 3

Plate 4
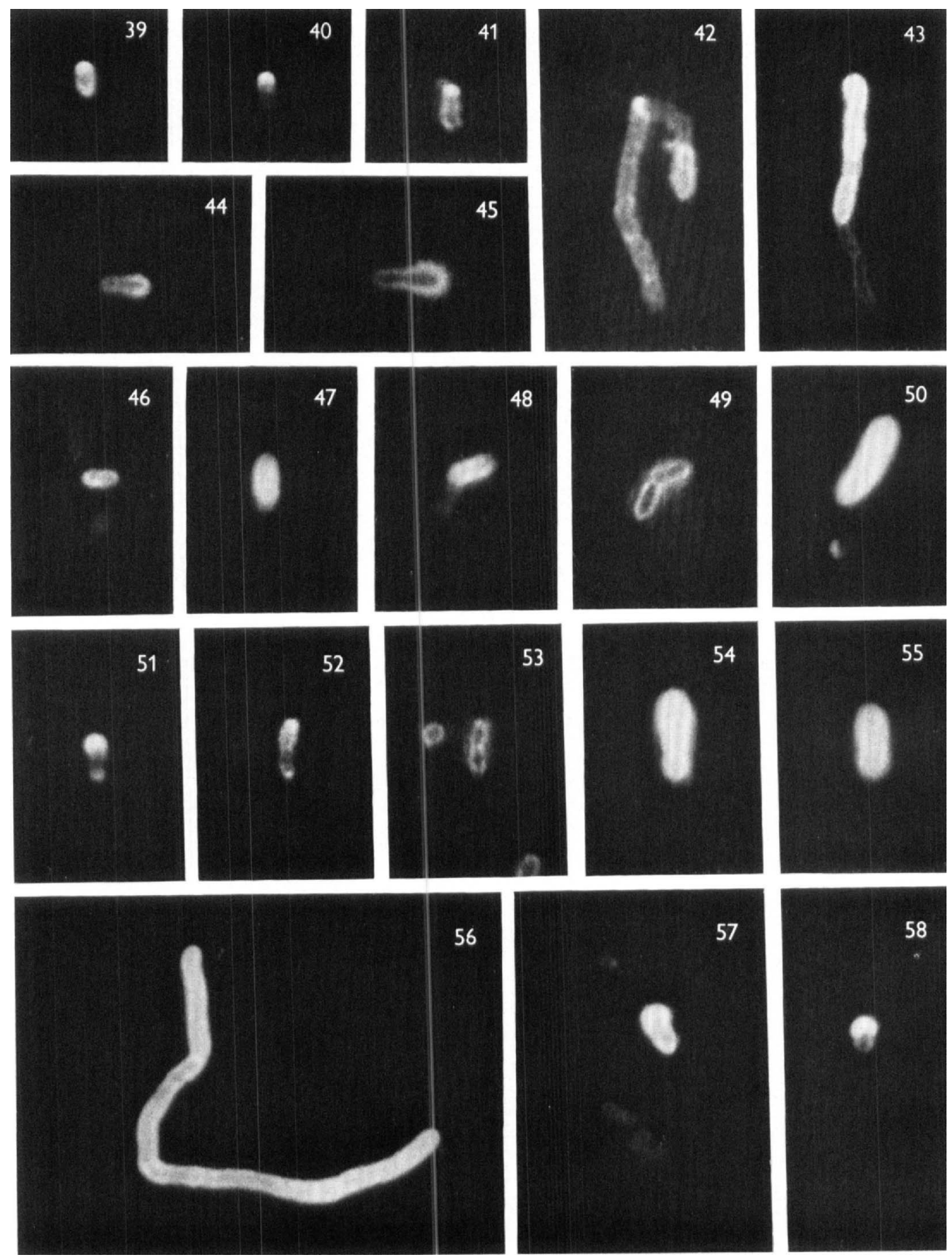

B. W. CATLIN AND V. R. TARTAGNI 
Journal of General Microbiology, Vol. 56, No. 3

Plate 5
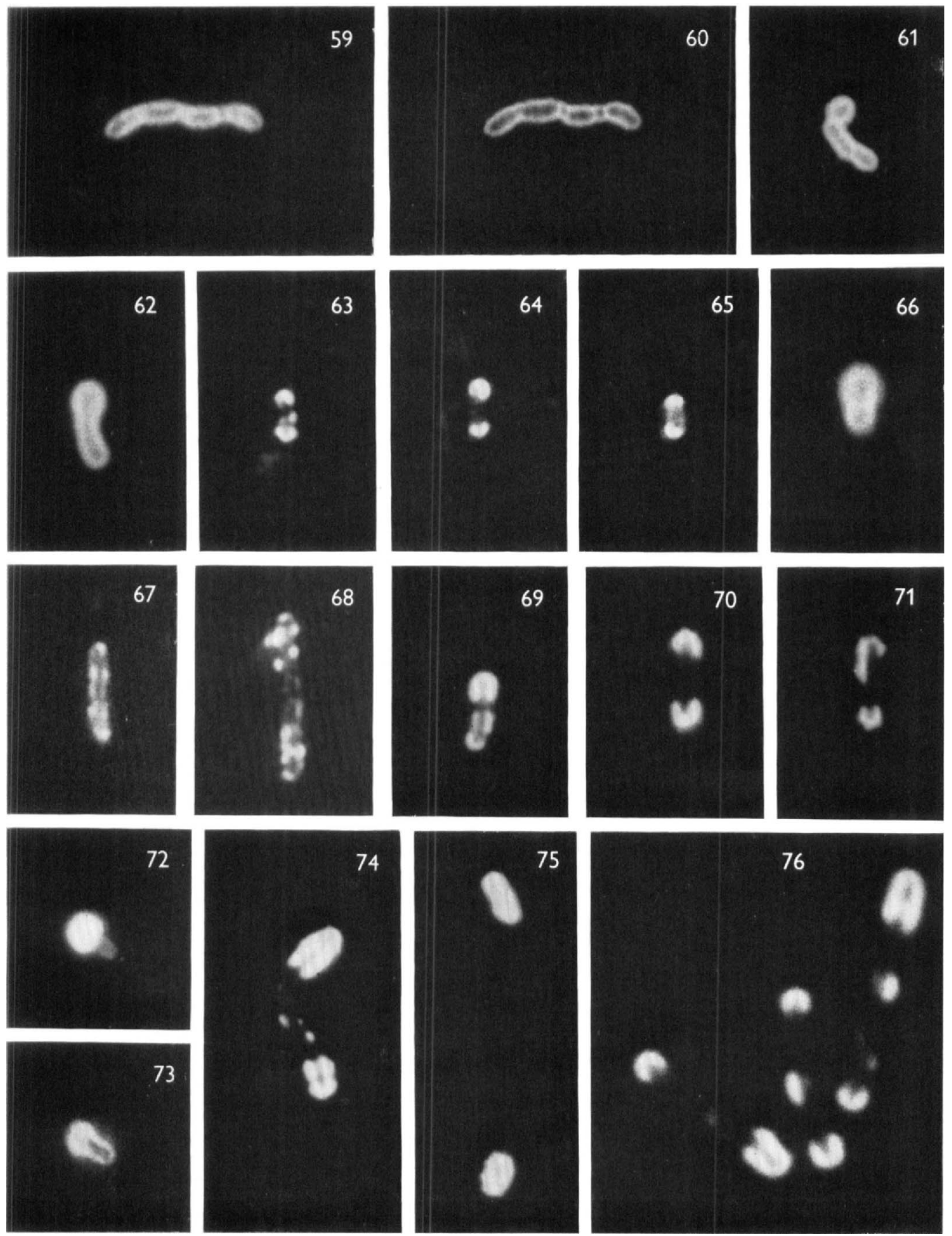

B. W. CATLIN AND V. R. TARTAGNI 
Journal of General Microbiology, Vol. 56, No. 3

Plate 6
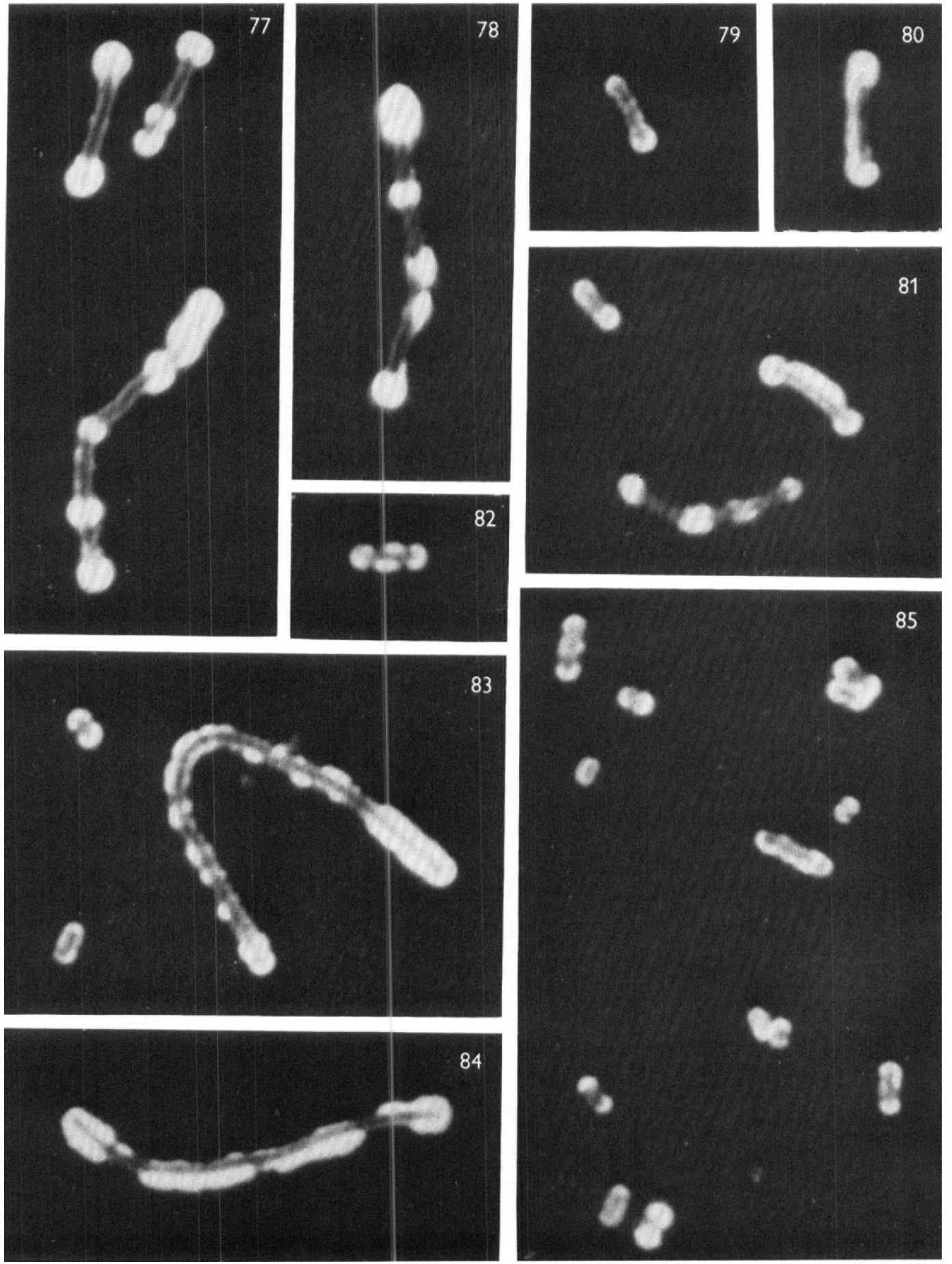

B. W. CATLIN AND V. R. TARTAGNI 
fluorescence of one capsulated bacterium in the chain at left (which contained only three bacteria). Fig. I 2, Microcolony of capsular transformants after $240 \mathrm{~min}$. total incubation; u.v., $30 \mathrm{sec}$; Fig. I3, tungsten exposure of a portion of the same field showing confluent growth of non-capsulated bacteria. Fig. 14, $105 \mathrm{~min}$. total incubation; u.v., $40 \mathrm{sec}$.

\section{Plate 3}

Capsular 'transformants' of strain RD elicited by treatment for $20 \mathrm{~min}$. with $\mathrm{I} \cdot 0 \mu \mathrm{g}$. of $\mathrm{DNA} / \mathrm{ml}$., except $0.01 \mu \mathrm{g} . / \mathrm{ml}$., Fig. 34; sampled after continuous cultivation in broth. U.v. exposures for all except Fig. I8. Fig. 15-16. DNA 4; cultivation in Levinthal broth. Fig. 15, 50 min. incubation. Fig. I6, $55 \mathrm{~min}$. incubation.

Fig. 17-1 8. DNA 4; cultivation in BHI+HD broth for 90 min. Fig. 17, u.v., 45 sec.; Fig. 18, tungsten exposure of the same bacterium.

Fig. 19. DNA 4 ; 105 min. incubation in BHI + HD broth.

Fig. 20-24. DNA 4; $240 \mathrm{~min}$. incubation in Levinthal broth.

Fig. 25-38. DNA 5; cultivation in BHI + HD broth. Fig. 25, 26, 60 min. incubation. Fig. 27-36, $120 \mathrm{~min}$. incubation. Fig. 37, 38, $210 \mathrm{~min}$. incubation.

\section{Plate 4}

Fig. 39-45. Capsular 'transformants' elicited by treatment with DNA 5 in the experiment plotted in text-fig. I-2. U.v. exposures. Fig. 39, I35 min. total incubation, diluted culture. Fig. 40, $195 \mathrm{~min}$. total incubation, diluted culture. Fig. 4I, 42, $240 \mathrm{~min}$. total incubation, diluted culture. Fig. 43-45, $255 \mathrm{~min}$. incubation of undiluted culture.

Fig. 46-58. Capsular 'transformants' elicited by treatment with DNA 2 in the experiment plotted in text-fig. 3. U.v. exposures for all except Fig. 49 and 53. Fig. 46, 40 min. incubation of undiluted culture. Fig. 47, 55 min. incubation of undiluted culture. Fig. 48, $70 \mathrm{~min}$. incubation of undiluted culture; one capsulated organism with attached non-capsulated bacterium, photographed with u.v.; Fig. 49, tungsten exposure of the same pair. Fig. 50, I 10 min. incubation of undiluted culture; a large capsulated bacterium lies above a small one with only a unipolar fluorescent cap. Fig. 5I, I 10 min. incubation of undiluted culture. Fig. 52, 120 min. incubation of undiluted culture, u.v.; Fig. 53, tungsten exposure of the same organism. Fig. 54, $120 \mathrm{~min}$. incubation of undiluted culture. Fig. 55, 180 min. incubation of undiluted culture. Fig. 56, 57, $195 \mathrm{~min}$. total incubation, diluted culture. Fig. 58, 225 min. total incubation, diluted culture.

\section{Plate 5}

Capsular 'transformants' of strain RD elicited by treatment for $20 \mathrm{~min}$. with various concentrations of DNA 2. U.v. exposures for all except Fig. 73 .

Fig. 59-68. Sampled after continuous incubation in BHI + HD broth. Fig. 59, 240 min. incubation, $0.3 \mu \mathrm{g}$. DNA $/ \mathrm{ml}$.; capsulated chain of organisms photographed with u.v., $35 \mathrm{sec}$.; Fig. 6o, the same chain rephotographed with a second $35 \mathrm{sec}$. exposure with u.v. revealing additional detail and reduced fluorescence. Fig. $6 \mathrm{I}-63,240 \mathrm{~min}$. incubation, $0 \cdot 3 \mu \mathrm{g}$. DNA/ml. Fig. $64-68,210$ or $300 \mathrm{~min}$. incubation, $\mathrm{I} \cdot 0 \mu \mathrm{g}$. DNA $/ \mathrm{ml}$.

Fig. 69-76. Impression preparations of cultures on HIY + HD agar. Fig. 69-7I, 240 min. total incubation, $\mathrm{I} \cdot 0 \mu \mathrm{g}$. DNA $/ \mathrm{ml}$. Fig. 72 , $180 \mathrm{~min}$. total incubation, $1 \cdot 0 \mu \mathrm{g}$. DNA $/ \mathrm{ml}$; ; bacterium with a large unipolar fluorescent cap, u.v.; Fig. 73, tungsten exposure of the same bacterium. Fig. 74, $270 \mathrm{~min}$. total incubation, $0.0 \mathrm{I} \mu \mathrm{g}$. DNA $/ \mathrm{ml}$. Fig. 75, $270 \mathrm{~min}$. total incubation, $\mathrm{I} \cdot 0 \mu \mathrm{g}$. DNA $/ \mathrm{ml}$.; two separate normally capsulated bacteria. Fig. $76,270 \mathrm{~min}$. total incubation, $0.15 \mu \mathrm{g}$. DNA $/ \mathrm{ml}$.

\section{Plate 6}

Fig. 77-85. Pure cultures on HIY + HD agar of strain RD(93I I) str-r $\mathbf{R}$, a very rough colonial isolate. U.v. Fig. $77-79,4 \mathrm{hr}$ incubation. Fig. 80-85, $23 \mathrm{hr}$ incubation. 